\title{
Consumer Decision-Making Styles and Local Brand Biasness: Exploration in the Czech Republic
}

\author{
- Wanninayake W.M.C.Bandara
}

\begin{abstract}
The modern marketer shows a growing interest in the research of consumer decision-making styles to understand how an individual makes his/her buying decisions in the competitive environment. This concept is important because it determines the behavioral patterns of consumers and is relevant for market segmentation. Most of the previous researchers have adapted to Consumer Style Inventory (CSI) introduced by Sproles and Kendall in 1986 as a common tool for assessing the decision-making styles of customers. Though researchers have validated CSI in different cultural and social contexts, very limited studies were carried out to explore the relationship between consumer decision-making styles and their domestic brand biasness. Therefore, the present study mainly focuses on exploring the impact of consumer decision-making styles on their preference towards domestic brands in the context of the Czech Republic. The sample for this study was drawn from adult customers who live in the Brno, Zlin, and Olomouc regions in the Czech Republic. A group of students from the Bachelor's degree programme in Management and Economics, Tomas Bata University in Zlín were selected as enumerators for data collection. Altogether 200 questionnaires were distributed and 123 completed questionnaires were taken in for final analysis. The decision- making styles were measured using Sproles and Kendall's (1986) CSI instrument. Cronbach's Alpha values of each construct confirmed that there is a good interring reliability associated with the data. Principle Component Analysis was employed to determine the decision-making styles of Czech customers and the one-way ANOVA was used for testing hypotheses. The findings revealed that seven decision-making styles are appeared among Czech customers and fashion consciousness, recreational orientation, impulsiveness, and price consciousness of customers show a direct relationship with the domestic brand biasness. Other styles did not show a significant relationship with domestic brand preferences in the given context. Finally, the researchers provide some suggestions for domestic firms in the Czech Republic to develop appropriate marketing strategies for attracting customers towards domestic brands.
\end{abstract}

Keywords: Consumer Style Inventory, Domestic brand biasness, Czech Republic, Consumer decision-making JEL Classification: M31, M30, M39

\section{BACKGROUND OF THE STUDY}

Consumer decision making styles have become a popular research area among academics in marketing and behavioral sciences. Most of the previous researchers have paid considerable attention on consumer shopping behavior and decision making styles which they are displaying in 
purchasing products in a modern retail environment. According to Sproles and Kendall (1986) consumer decision making style is a mental orientation characterizing a consumer's approach to making choices. Therefore examining this concept is important to marketing practices because it determines consumer behavior and is relevant for market segmentation (Sproles and Kendall, 1986; Walsh et. al, 2001). On the other hand consumer decision is a signal for marketers, whether a marketing strategy has been wise and insightful or whether it was poorly planned and missed the market. Hence understanding about consumer decision making is essential for both domestic and global businesses in crafting strategies.

In recent times, globalization has become a crucial phenomenon for any business in the world with its profound impacts in the short term and in the long term. Further, globalization leads to the homogenization of world markets and it allows multinational companies (MNCs) to mark their presence in the local markets by increasing the availability of a wider range of international brands in various host countries. As huge assets, sophisticated technology, knowledge and skills in terms of business operations of MNCs have enabled them to create undue opportunity to monopolize the markets of the host countries; domestic firms should find the strategic alternatives for stimulating customer preferences for domestic brands. Although several alternatives are available, most domestic marketers address this issue by utilizing ethnocentric brand appeals. Along with increased nationalism and heavy emphasis on cultural and ethnic identity, consumer ethnocentrism will be a potent force in the global business environment in the years to come.

According to Wanninayake and Chovancova (2012), the domestic firms make ethnocentric appeals with the purpose of increasing local brand biasness of the customers. However Wang and Hui (2004) argue that the consumers' preference to buy foreign or local brands mainly depends on their decision making styles. Further some famous researchers like Shimp and Sharma (1987) noted that customers decide to buy local or foreign products based on their degree of ethnocentric tendencies. Furthermore Shankarmahesh (2006) explored that CET has several antecedents and consumer decision making styles become a socio psychological antecedent of CE. On the other hand Vida, et al., (2008) empirically validated that CET has direct impact on local brand biasness. Therefore the present researchers reasonably assumed that consumer decision making styles may have significant impact on domestic brand biasness of the customers.

Even though previous research findings provide rich information about the consumer decision making styles, very limited studies only focus on relationship between consumer decision making styles and domestic brand biasness of the customers. Furthermore Hanzaee and Aghasibeig (2008) noted that there is no universally accepted model for understanding consumer shopping styles and most of researchers have adopted to the Consumer Style Inventory (CSI) developed by Sproles and Kendall (1986) as a comprehensive instrument. Therefore the main purpose of the present study is to explore the impact of consumer decision making styles of CSI on domestic brand biasness of the customers in the context of Czech Republic.

The significance and expected knowledge contribution of this study will veer into three aspects. In general, this study will draw attention to the consumer CSI as an important phenomenon for researching different contexts for analyzing consumer decision making styles. It will aim at providing suggestions for further researches as well. In the theoretical perspective it will contribute to developing a comprehensive understanding and application of previous research findings to 
correlate those phenomenons. In the practical aspect, this study will aim to provide guidelines to marketers of domestic companies to identify potential segments to promote ethnocentric appeals for stimulating local brand of customers. In this article the researchers will first discuss the background of the study. Then will continue by presenting the critical literature in the respective area and hypotheses and methodology. Research findings and discussions will be presented in section five, followed by the conclusion in the final section.

\section{LITERATURE REVIEW}

\subsection{Consumer decision-making styles}

As mentioned above, decision making style is one of the crucial factors in consumer purchase decision. Therefore studying consumer decision making styles can be categorized into three main approaches namely psychographic/lifestyle approach, consumer typology approach and consumer characteristics approach. Psychographic/ lifestyle approach includes many characteristics of consumer behavior. Consumer typology approach identifies customer into several types and consumer characteristics approach aims on different cognitive dimensions of consumer decision making.

According to Lysonksi et.al (1996), the consumer characteristics approach is the most dominant and descriptive approach among these three approaches. Hence this approach focuses on the mental orientation of consumers in making decisions. Therefore decision making styles can be found by identifying the general orientation of consumer towards shopping and buying. Studying underlying decision styles of shoppers, under the field of consumer behavior literature has a long history since the 1950's. Most of these studies revealed that all consumers approach shopping with certain decision making traits that combine to form a consumer decision making styles. Accordingly the previous studies have disclosed considerable number of aspects regarding consumer decision making behavior (e.g. Darden and Reynolds 1971; Sproles and Kendal 1986; Hafstrom et al. 1992; Durvasala et.al. 1993; Lysonski et al. 1996; Mitchell and Walsh 2004). These studies have broadly categorized them as being based on shopping orientation, store patronage, consumer decision making styles and information search behavior etc.

In the context of consumer characteristics approach, Sproles (1985) developed an instrument to profile the decision making styles of consumers. This instrument consisted with 50 items, related to consumers' cognitive and affective orientation towards shopping activities. Data collection was carried out from 111 undergraduate women in two classes at the University of Arizona. Using Factor Analysis technique Sproles found six consumer decision making style traits namely, perfectionism, value conscious, brand consciousness, novelty fad fashion consciousness, shopping avoider, time saver and confused support seeking decision maker. Sproles and Kendall further refined this inventory and developed a more parsimonious scale called Consumer Style Inventory (CSI) in 1986. The CSI comprised with 40 items on consumer decision making styles characteristics. The instrument was administered to 482 students in 29 home economics classes in five high schools in the Tucson, Arizona area. This instrument measured 8 mental characteristics of consumer decision as, perfectionism, brand consciousness, novelty and fashion consciousness, recreational, price value consciousness, impulsiveness, confused by over choice and brand loyal and habitual. 
According to Sproles and Kendall (1986), high quality conscious customers search carefully and systematically for the highest or very best quality in products and brand conscious people are buying the most expensive and well-known brands. On the other hand novelty and fashion conscious customers like new and innovative products for gaining excitement from seeking out new things. Further Sproles and Kendall (1986) noted that recreational and shopping conscious individuals consider shopping as a pleasant activity and shops just for the fun of it. However price conscious customers are seeking high value for money. Furthermore those researchers found that impulsive customers never plan their shopping and tend to buy on the spur of the moment. Confused by over choice customers perceive too many brands and stores from which to choose and who likely experience information overload in the market. As last decision making style of CSI, Sproles and Kendall (1986) suggested habitual/brand loyal consumers who have favorite brands and stores.

After introducing aforesaid eight decision making styles, many researchers in consumer behavior had employed CSI as a tool for analyzing shopping behavior of customers. According to the empirical studies in different socio cultural contexts, CSI items has been loaded into different factors and revealed some additional decision making patterns as well. Even though few researchers argue that generalizability of CSI instrument has not been established by previous studies (e.g. Yasin, 2009; Canabal, 2002), most of the previous authors commonly accept CSI as reliable measurement for analyzing consumer shopping behavior in different contexts in the world. Therefore it is worth to analyze the adoptability of CSI for analyzing consumer behavior in the context of Czech Republic.

\subsection{CSI adoptability in cross cultural perspectives}

The development of CSI was significant milestone in consumer decision making research. CSI has contributed in providing a good foundation for comparing the results with prior research (e.g. Hafstrom et.al. 1992, Durvasula et.al. 1993; Lysonski et.al. 1996; Walsh et.al. 2001). In addition to that this instrument will assist to reduce the conceptual and measurement differences and identifying differences in decision making styles in different countries and cultures. Accordingly, Durvasula et.al. (1993) noted that the dimensionality and reliability of CSI is acceptable in New Zealand context. They found eight consumer decision making styles which are similar to the original CSI scales. Research carried out by Hafstrom et.al., (1992) found that seven of the eight factors of Sproles and Kendall's CSI among Korean customers. Novelty and fashion consciousness was not confirmed in the study. Those researchers attributed this to the possible links between 'brand consciousness' and 'fashion consciousness' among young Korean consumers. The additional factor was named as "Time-energy Conserving Consumer". Further Lysonski et.al (1996) argued that the eight factor solution was found to be difficult to interpret for the Greek and Indian customers and it is applicable in New Zealand and USA contexts. Furthermore Walsh et.al (2001) explored that six consumer decision making styles are only confirmed in the Germany. According to Mitchell and Bates (1998) the inventory was vital to assess cultural differences and produced meaningful results. But they were doubtful about the generalizability of the original CSI research findings among different cultures. As far as applicability of CSI in developing countries are concerned, Fan and Xiao (1998) tested CSI in Chinese context and found only five decision making styles are applied to young Chinese consumers. They further 
concluded that consumer commodity market is different in China than US and Korea. Therefore some limitations can be identified against generalizability of the inventory across those countries. Further Canabal, (2002) confirmed five decision styles in the empirical study in South India. According to the aforesaid findings of empirical studies, the present researchers noted that CSI can be applied in both developed and developing countries for investigating consumer decision making styles.

\subsection{Consumer ethnocentrism and domestic brand biasness}

Ethnocentrism is a sociological phenomenon discovered by William G. Sumner (1906) in the first decades of the nineteenth century. Initially, this concept was referred to with the purpose of differentiating between one's own group from others. According to Summer (1906), ethnocentrism is "the technical name for the view of things in which one's own group is the centre of everything, and all others are scaled and rated with reference to it". On the other hand, ethnocentrism is the feeling that let's one believe that his/her life style, values, norms, customs and adaptation pattern of his/her own group is superior to those of other groups (Columbia Encyclopedia, 2011). Therefore, it can be further explained as a tendency of people to believe that their cultural or ethnic group is superior to others and all other groups are evaluated based on the cultural and social values of their own group. According to Adorno et al. (1950), ethnocentrism can be conceptualized as "ethnic centeredness" and the rigidity in accepting what are similar cultural or social values while rejecting whatever is different in terms of cultural or social values. Generally, a highly ethnocentric person may judge other groups relative to his/her cultural dimensions such as language, behavior, customs, and religion of his or her own group.

Even though the aforementioned concept was originally developed from a sociological perspective, later it became a psycho-social construct with great relevance to individualistic personality systems and cultural and social analytic frameworks in general (Levine and Campbell, 1972). In a broader perspective, people in different countries evaluate their inherent products as superior to that of other nations' and show a tendency to use their own products rather than foreign made products. Analyzing ethnocentrism together with consumer behavior from the perspective of consumer economic behavior results in "consumer ethnocentrism (CE)." With this background, CE has become a very popular phenomenon in marketing and consumer behavior. Generally, CE expresses the effects of buying intentions regarding home-grown products instead of those products from countries that are perceived to be different from the home country (Kaynak and Kara, 2002). Moreover, CE calls into question the appropriateness of preferring foreign-made products over domestic products (Shimp and Sharma, 1987). Highly ethnocentric individuals perceive their national values and symbols as sources of pride and often despise the values of others and are intolerant of cultural differences of other nations (Luque-Martinez et al., 2000). According to Shimp and Sharma (1987), highly ethnocentric consumers believe that buying foreign products badly affects the economy of home country.

According to the above discussion, it can be conceptually argued that CET is positively correlated to purchasing or favorable evaluation of domestic products. On the other hand, it will also stimulate customers to reject or unfavorably evaluate foreign made products as well. According to Shankarmahesh, (2006) previous researchers have given several operational definitions for 
possible consequences of CE. This outcome has been operationalized by previous researchers in different ways such as attitudes towards buying foreign products (Sharma et al., 1995), willingness to buy foreign products (Klein et al. 1998, Suh and Kwon 2002), purchasing intention of local products (Han 1988), willingness to buy domestic products (Olsen et al., 1993; Wang and Chen, 2004), willingness to buy foreign products (Klein et al., 1998), favorable evaluation of domestic products attributes (Chryssochoidis et al., 2007), domestic brand preference (Siemieniako et. al, 2011), local brand biasness (Vida, et al., 2008), supporting foreign retail outlets (Zarkada-Fraser and Fraser, 2002), visiting art exhibitions of home country artists and artists from culturally similar countries (Kottasz and Bennett, 2005), product receptivity (Orbaiz and Papadopoulos, 2003) etc. Even though previous authors introduced several consequences of CE, all of them had more or less emphasized that CET will be helped to stimulate domestic brand biasness.

As per the above discussion, it is noted that CE may naturally stimulate the customers' preferences of home-made products. Further consumers adapted to several decision making styles in their purchasing decisions. However the most important issues are whether Czech customers display all decision making styles suggested by Sproles and Kendall (1986) and whether domestic brand biasness of Czech people is varied in those behavioral patterns. Therefore those issues mainly addressed in the present study.

\section{HYPOTHESES}

According to Herche (1992), consumers evaluate foreign made products differently than domestic products. Most of the researchers argue that when information about the product is lacking, consumers have a general preference for domestic-made products over foreign products in developed countries (e.g. Damanpour 1993; Elliott and Camoron, 1994). Further Morganosky and Lazarde (1987) noted that quality image associated with imported products is lower than domestic products in the developed countries. Therefore Toyne and Walters (1989) argue that there is a positive correlation between domestic product evaluations and the economic development of the country of origin. On the other hand, consumers show more preference to the imported products in developing countries (Agbonifoh and Elimimian 1999; Wang et al. 2000). Therefore Piron (2000) argued that customers display conspicuous consumption pattern in purchasing foreign products. Further McDonald (1994) noted that well off customers are motivated to buy imported products in order to satisfy the social factors rather than economic or physiological utility of products. Furthermore Wang et.al. (2002) argue that brand consciousness is becoming increasingly important factor among the customers who are willing to buy foreign products. Moreover Wang et.al. (2002) empirically proved that customers who are willing to buy imported products display high degree on quality conciseness, brand conciseness, fashion conciseness as well as impulsiveness and brand loyalty. However they are less price conciseness and confused by over choice. Further there is no relationship between preferences for the foreign products and recreational and hedonistic orientation of the customers. Based on the empirical results, Kaynak and Kara (2001) claimed that more fashion oriented customers are low ethnocentric. Additionally, Kucukemiroglu (1999) explored that both fashion consciousness and leadership concerns of Turkish customers negatively correlates with CET. Based on the preceding discussion, research- 
ers have formed five hypotheses to determine the relationship between decision making styles and the local brand biasness of Czech customers.

H1: The high-quality conscious and brand conscious Czech consumers are being less biased towards domestic brands

H2: The fashion conciseness, brand loyal and impulsive Czech consumers are being less biased towards domestic brands

H3: The price conscious Czech consumers are being more biased towards domestic brands

H4: The confused by over choice Czech consumers are being more biased towards domestic brands

H5: The recreational/hedonistic orientated Czech consumers are being less biased towards domestic brands

\section{RESEARCH METHOD}

The respondents of this study were adult customers who live in the Brno, Zlín, Olomouc regions in the Czech Republic. They were selected based on the convenience sampling method, mainly through the students of Tomas Bata University in Zlin. The students of marketing research course of the bachelor's degree programme in Management and Economics were selected as enumerators for data collection. They collected data through a self-administrated questionnaire from the adult customers in Zlin region. Altogether 200 questionnaires were distributed; only 123 completed questionnaires were taken into the final analysis. The sample consisted of a higher proportion of female respondents (53.6 percent) than male respondents (46.4 percent). In addition, 36.5 percent of the customers were students and 41.4 percent of the customers held graduate and post graduate qualifications. As per the age distribution, the majority of respondents (45.5 percent) were aged between 18 - 30 years. Therefore the demographic structure of the sample was sufficient to examine the research issue of the given context.

This study's survey instruments were developed based on previous studies. Consumer Style Inventory (CSI) developed by Sproles and Kendall (1986), was used to measure the decision making styles of the respondents with some modifications to fit with the Czech context. This scale has been validated by different studies in different countries by previous researchers. In all the previous studies it has reported sufficient value of Cronbach's alpha as an indicator of the reliability of the scale. Local brand biasness was operationalized as consumer preferences for domestic brands, in that consumers intentionally take time to identify these products while shopping. Even though there is no universally accepted scale to measure the local brand biasness, Vida, et al., (2008) adapted to the selected items of Granzin and Olsen's (1998) scale measuring consumer helping behavior for estimating local purchasing biasness in European context. Therefore present researchers used two items of this scale to measure local brand biasness. All the scales were scored on a seven point likert scale ranging from 1 (strongly disagree) to 7 (strongly agree). 


\section{DISCUSSION OF RESULTS}

The IBM SPSS 19 package was employed for data analysis. The outcome of the analysis is reported in the first part of this section. Further findings and their possible consequences are also discussed here in detail. Initially, a reliability analysis was done to measure the internal consistencies of the total scores for each scale through Cronbach's Alpha Coefficients. The calculation of reliability measurements is presented in table 1 . As per the findings, all the reliabilities for both scales are found to be adequate since Cronbach's Alpha values are higher than 0.8 (According to George and Mallery (2003), Cronbach Alpha > .9 - Excellent, _ $>.8$ - Good, ${ }_{-}>.7$ - Acceptable, ${ }_{-}>.6$ - Questionable, $\_>.5$ - Poor, and $<.5$ - Unacceptable)

Tab. 1 - Reliability analysis for the Scale. Source: Survey data 2013.

\begin{tabular}{|l|l|l|}
\hline Scales & No. of Items & Cronbach's Alpha \\
\hline CSI & 40 & .811 \\
\hline Local brand biasness & 02 & .824 \\
\hline
\end{tabular}

In addition to the reliability statistics of the initial stage, EFA was initially conducted with the purpose of grouping 40 items for the different factors. In the data screening process, major assumptions to the factor analysis was tested. Accordingly missing data were replaced by responses of respondents who are in similar demographic characteristics based on hot or cold deck imputation techniques. Normality was tested based on multivariate normality test. Further homoscadasity was assured based on Levene test for each of the non metric variable across the metric variables in the data base. Further multicoliniarity was tested by using the criteria of Squared Multiple Correlation (SMC), Tolerance Statistics and Variance Inflation Factor (VIF). Linearity was further assured based on residual plots. As all assumptions were satisfactory met and it was assumed that data set is appropriate to conduct factor analysis.

According to the inter item correlation matrix, all correlation coefficients were reported within the range between 0.3 to 0.8 and it was further assured that data is free from multicolinearity issues. Furthermore Kaiser-Meyer-Olkin (KMO) test and Bartlett's Test were conducted to test the factorability and sample adequacy for the factor analysis. It ensured the sample adequacy due to KMO value was 0.836 . Further Chi-Square 6.711 of Bartlett's test was highly significant $(\mathrm{p}<0.001)$. As a basic requirement for the factor analysis is satisfied, principle component analysis based on varimax rotation was adopted and extracted factors with greater than 01 eigenvalue.

According to the rotated component matrix, 34 items were loaded into 07 factors and total variance of those factors was $66.95 \%$. Summary of factor loading, eigenvalues and variance explained in each factor are summarized into table 3. 
Tab. 2 - Rotated Component Matrix for CSI. Source: Survey data 2013.

\begin{tabular}{|c|c|c|c|}
\hline Factors & $\begin{array}{l}\text { Factor } \\
\text { loading }\end{array}$ & $\begin{array}{l}\text { Eigen } \\
\text { values }\end{array}$ & $\begin{array}{l}\text { Variance } \\
\text { Explained }\end{array}$ \\
\hline Brand Consciousness (7 items) & & 5.365 & 21.612 \\
\hline The most advertised brands are usually very good choices. & .821 & & \\
\hline I prefer buying the best-selling brands. & .733 & & \\
\hline The more expensive brands are usually my choices. & .696 & & \\
\hline The higher the price of a product, the better its quality. & .612 & & \\
\hline Once I find a product or brand I like, I buy it regularly. & .592 & & \\
\hline I have favorite brands which I buy over and over again. & .570 & & \\
\hline I change brands I buy regularly. & .493 & & \\
\hline Perfectionist, high-quality consciousness (5 items) & & 4.236 & 14.251 \\
\hline Getting high quality is very important to me. & .811 & & \\
\hline $\begin{array}{l}\text { When it comes to purchasing products, I try to get the very } \\
\text { best or the perfect choice. }\end{array}$ & .791 & & \\
\hline $\begin{array}{l}\text { I make special effort to choose the very best quality prod- } \\
\text { ucts. }\end{array}$ & .629 & & \\
\hline In general, I usually try to buy the best overall quality. & .602 & & \\
\hline $\begin{array}{l}\text { My standards and expectations for products I buy are very } \\
\text { high. }\end{array}$ & .543 & & \\
\hline Recreational, bedonistic consumer (5 item) & & 3.211 & 11.613 \\
\hline Shopping is not a pleasant activity to me (R). & -.796 & & \\
\hline Shopping in a supermarket wastes my time (R). & -.691 & & \\
\hline Going shopping is one of the enjoyable activities of my life. & .556 & & \\
\hline I enjoy shopping just for the fun of it. & .522 & & \\
\hline I make my shopping trips fast. & .491 & & \\
\hline Impulsiveness (5 items) & & 2.164 & 8.566 \\
\hline Often I make careless purchases I later wish, I had not. & .784 & & \\
\hline $\begin{array}{l}\text { I normally shop quickly, buying the first product or brand } \\
\text { that seems good enough. }\end{array}$ & .722 & & \\
\hline $\begin{array}{l}\text { I believe product doesn't have to be exactly what I want, or } \\
\text { the best on the market to satisfy me. }\end{array}$ & .686 & & \\
\hline $\begin{array}{l}\text { I spend little time deciding on the products and brands I } \\
\text { buy. }\end{array}$ & .520 & & \\
\hline I should plan my shopping more carefully than I do. & .511 & & \\
\hline Price-Value Consciousness (4 items) & & 1.812 & 4.938 \\
\hline I buy as much as possible at sale price. & .694 & & \\
\hline I carefully watch how much I spend. & 632 & & \\
\hline
\end{tabular}




\begin{tabular}{|c|c|c|c|}
\hline I look carefully to find the best value for the money. & .620 & & \\
\hline The lower price products are usually my choice. & .515 & & \\
\hline Confused by Over choice (4 items) & & 1.521 & 3.244 \\
\hline $\begin{array}{l}\text { There are so many brands to choose from, that often I feel } \\
\text { confused. }\end{array}$ & .741 & & \\
\hline Sometimes it is hard to choose which supermarket to shop. & .677 & & \\
\hline $\begin{array}{l}\text { The more I learn about products, the harder it seems to } \\
\text { choose the best. }\end{array}$ & .631 & & \\
\hline $\begin{array}{l}\text { All the information I get on different products confuses } \\
\text { me. }\end{array}$ & .502 & & \\
\hline Novelty fashion conscious consumer (4 items) & & 1.212 & 2.728 \\
\hline I keep my wardrobes up to date with the changing fashions. & .693 & & \\
\hline Fashionable attractive styling is very important to me. & .645 & & \\
\hline I usually have one or more outfits of the very newest style. & .608 & & \\
\hline $\begin{array}{l}\text { To get variety, I shop different stores and choose different } \\
\text { brands. }\end{array}$ & .574 & & \\
\hline
\end{tabular}

$\mathrm{R}=$ Reverse coded items

Results showed that a seven-factor solution was more interpretable. Items that had a factor loading less than 0.4 on its primary factor and items that had substantial cross-loading(s) were removed. This resulted in the removal of 06 items. According to the structure of factor loading of remaining items, researchers named the factors in line with Sproles and Kendall (1986) when they reflect similar decision-making characteristics. Accordingly habitual, brand-loyal consumer pattern were removed and other seven decision making styles were considered in labeling the seven factors. Most of items belong to the habitual, brand-loyal consumer pattern were loaded in to brand consciousness style of original CSI model. Further reliability of those factors was re tested by using Cronbach's alpha and all seven factors were recorded above 0.70 Cronbach's alpha values. Therefore both reliability and construct validity were assured in the data set.

\subsection{CSI Segments and local brand biasness}

As per the details given in methodology section, local brand biasness was operationalised as consumer preference for selecting domestic brands in the shopping contexts. Accordingly two items were used for measuring local brand biasness of Czech customers. The findings revealed that generally local brand biasness of the Czech customers is at a moderate level $(\mathrm{M}=5.84, \mathrm{SD}=$ 0.8142). However the main issue of the study is to evaluate the impact of decision making styles on local brand biasness of Czech customers. Therefore, the researchers divided the total sample into two clusters based on their degree of local brand biasness. Accordingly, the customers who recorded above the average mean values for the two question items of local brand biasness were categorized as high local brand bias customers and customers who reported below the average were named as low local brand bias customers. Finally, the local brand biasness of the customers were analyzed relating to each decision making pattern identified in the factor analysis. The results are given in the table 03 . 
Tab. 3 - Consumer decision making styles and domestic brand biasness. Source: Survey data 2013.

\begin{tabular}{|l|c|c|c|}
\hline Decision making styles & $\begin{array}{l}\text { High local brand } \\
\text { bias customers } \\
(\mathrm{N}=49)\end{array}$ & $\begin{array}{l}\text { Low local brand } \\
\text { bias customers } \\
(\mathrm{N}=74)\end{array}$ & $\begin{array}{l}\text { ANOVA } \\
\text { p value }\end{array}$ \\
\hline $\begin{array}{l}\text { Perfectionist, high-quality conscious } \\
\text { consumer }\end{array}$ & 3.71 & 3.76 & 0.00 \\
\hline Brand conscious consumer & 3.61 & 3.44 & 0.00 \\
\hline Novelty, fashion conscious consumer & 2.82 & 3.26 & 0.40 \\
\hline Recreational, hedonistic consumer & 3.11 & 3.18 & 0.51 \\
\hline Price conscious consumer & 3.65 & 3.12 & 0.46 \\
\hline Impulsive consumer & 2.13 & 2.31 & 0.00 \\
\hline Confused by over choice consumer & 2.27 & & \\
\hline
\end{tabular}

According to the findings given in the table 03 , there were significant differences in local brand biasness $(p<0.05)$ on four factors of consumer-decision making styles (novelty-fashion consciousness, recreational-hedonistic, price consciousness and impulsiveness). As compared to high local brand bias consumers, low local brand bias consumers appeared to be more noveltyfashion consciousness, more recreational-hedonistic oriented, more impulsive and less price conscious. Further brand loyalty was not recognize as a separate decision making pattern of Czech customers in the factor analysis. However, on the other three factors no significant differences $(\mathrm{p}>0.05)$ in consumer decision styles between high and low local brand bias customers were found. Therefore the empirical results were supported to H2, H3, and H5. Therefore the researchers concluded that more fashion conscious, impulsive, and recreational oriented customers have less preference to buy the domestic Czech brands. Further it was noted that price conscious customers are preferred to buy domestic brands in Czech Republic. On the other hand H1 and $\mathrm{H} 4$ were not supported by the empirical results of the study. Therefore the researchers concluded that there is no significant difference in brand consciousness, quality consciousness and confused by over choice of customer between more ethnocentric and less ethnocentric customers.

\section{CONCLUSION}

The present study has been mainly focused on investigating the decision making styles of Czech customers and their local brand biasness. The empirical evidences support the three hypotheses and reject the two hypotheses. Therefore it reveals that more fashion conscious, recreational oriented, impulsive Czech customers are less ethnocentric and price conscious customers are more prefer to buy domestic brands. Further it was noted that consumer characteristics such as quality consciousness, brand consciousness, and confused by over choice do not have material impact on the ethnocentric feelings and local brand preferences of Czech customers. However habitual, brand-loyal pattern of consumer behavior did not appeared among Czech customers. These findings are confirmed with the previous research evidence and theories. For instance some researchers (E.g. McDonald, 1994) argue that high fashion conscious, recreational oriented and impulsive customers are youngsters and high income individuals who are less ethnocentric 
customers. Further some authors (E.g. Wang et.al, 2002) explored that quality consciousness and brand consciousness people represent the high income groups and display low biasness towards domestic brands. Furthermore it can be reasonably assumed that habitual customers are belonging to less educated and low income groups. Accordingly the results of the study offer some implications to the domestic marketers in the Czech Republic to rethink about their current marketing strategies. Especially domestic marketers of local Czech firms should use ethnocentric brand appeals to attract more customers in growing segments. Furthermore, they can use the findings of the study in segmentation and positioning of their products in the domestic market.

This study was characterized by several limitations that restrict the reliability to generalize the findings. First, the study was restricted to the few regions in the Czech Republic. Therefore it may be possible to obtain different results in the case of conducting the study in other parts of the Czech Republic. Furthermore, the data was collected from students of TBU with using self administrated questionnaires. Thus it is possible that these respondents may have provided highly subjective responses. Therefore further research can be designed to investigate this issue in different areas of the Czech Republic using random or stratified sampling techniques to represent the total population in the Czech Republic. Furthermore, future researches could investigate the impact of consumer decision making styles in considering the country of origin of imported products as well.

\section{Acknowledgement}

Authors are thankful to the Internal Grant Agency of FaME TBU No. IGA/FaME/2013/027/Strategic responses of Czech domestic firms for the emerging consumer behaviour trends under cross-cultural influences: a study in consumer and organizational perspectives for financial support to carry out this research.

\section{References}

1. Adorno, T. W., Frenkel-Brunswik, E., Levinson, D. J., \& Sanford, R. N. (1950). The authoritarian personality. NY: Harper \& Row.

2. Agbonifoh, B. A., \& Elimimian, J. U. (1999). Attitudes of developing countries towards 'country-of-origin' products in an era of multiple brands. Journal of International Consumer Marketing, 11(4), 97-116. http://dx.doi.org/10.1177/097226290601000306

3. Canabal, M.E. (2002), Decision Making Styles of Young South Indian Consumers: An Exploratory Study. College Student Journal, 36(1), 12-20. http://dx.doi.org/10.5296/jmr. v4i2.1222

4. Cheng-Lu Wang, Noel Y.M. Siu, \& Alice S.Y. Hui. (2004). Consumer decision-making styles on domestic and imported brand clothing. European Journal of Marketing, 38(1/2), 239252. http://dx.doi.org/10.1108/03090560410511212

5. Chryssochoidis G, Krystallis A, \& Perreas P. (2007). Ethnocentric beliefs and countryof-origin (COO) effect: impact of country, product and product attributes on Greek consumers' evaluation of food products. European Journal of Marketing, 41(11/12), 1518-1544. http://dx.doi.org/10.1108/03090560710821288

6. Damanpour, F. (1993). Temporal shifts of developed country-images: a 20 year view. In Papadopoulos, N. and Heslop, L.A. (Eds.), Product-Country Images: Impact and Role in International Marketing. International Business Press, New York, NY. 
7. Darden, W. R., \& Reynolds, F. D. (1971). Shopping orientations and product usage rates. Journal of Marketing Research, 8(4), 505-508. http://dx.doi.org/10.2307/3150244

8. Durvasula, S., Lysonki, S., \& Andrews, J. (1993). Cross cultural generalisability of a scale for profiling consumers decision making Styles. Journal of Consumer Affairs, 27(1), 33-75. http://dx.doi.org/10.1111/j.1745-6606.1993.tb00737

9. Fan, J. X., \& Xiao, J. J. (1998). Consumer decision making styles of young-adult Chinese. Journal of Consumer Affairs, 32(2), 275-294. http://dx.doi.org/10.1111/j.1745-6606.1998. tb00410.x

10. George, D., \& Mallery, P. (2003). SPSS for Windows step by step: A simple guide and reference. Boston: Allyn \& Bacon.

11. Hafstrom, Jeanne J., Jung Sook Chae, \& Young Sook Chung (1992). Consumer decisionmaking styles: comparison between United States and Korean Young Consumers. The Journal of Consumer Affairs, 26(1), 146-158. http://dx.doi.org/10.1111/j.1745-6606.1992. tb00020.x

12. Han, C.M. (1988). The role of consumer patriotism in the choice of domestic versus foreign products. Journal of Advertising Research, June/July, 25-32.

13. Hanzaee, K.H., \& Aghasibeig, S. (2008). Generation Y female and male decision-making styles in Iran: are they different? International Review of Retail, Distribution \& Consumer Research, 18(5), 521-537. http://dx.doi.org/10.1080/09593960802573443

14. Herche, J. (1992). A note on the predictive validity of the CETSCALE. Journal of the Academy of Marketing Science, 20(Summer), 261-274.

15. Kaynak, E., \& Kara, A. (2002). Consumer perceptions of foreign products. European Journal of Marketing, 36(7/8), 928-949. http://dx.doi.org/10.1108/02651330810887477

16. Klein, J.G., Ettenson, R., \& Morris, M. (1998). The animosity model of foreign product purchase: an empirical test in the People's Republic of China. Journal of Marketing, 62(1), 89100. http://dx.doi.org/10.2307/1251805

17. Kottasz. R., \& Bennett, R. (2005). The impact of ethnocentrism on perceived reputation and emotional liking of artworks: A comparative analysis. International Review on Public and Nonprofit Marketing, 2(2), 9-21. http://dx.doi.org/10.1017/S0140525X0999152X

18. Kucukemiroglu, O. (1999). Market segmentation by using consumer lifestyle dimensions and ethnocentrism: an empirical study. European Journal of Marketing, 33(5/6), 470-487. http://dx.doi.org/10.1108/17554191211274776

19. Levine, R.A., \& Campbell, D.T. (1972). Ethnocentrism: Theories of Conflict, Ethnic Attitudes, and Group Behavior. New York: Wiley.

20. Luque-Martinez, T., Ibanez-Zapata, J. A., \& Barrio-Garcia, S. (2000). Consumer ethnocentrism measurement:an assessment of the reliability and validity of the CETSCALE in Spain. European Journal of Marketing, 34(11/12), 1353-1373. http://dx.doi. org/10.1108/03090560010348498

21. Lysonski, S., Durvasula, S., \& Zotos, Y (1996), Consumer decision making styles: A multi country investigation. European Journal of Marketing, 30(12), 10-21. http://dx.doi.org/10.1108 /03090569610153273 
22. McDonald, W.J. (1994). Psychological associations with shopping: a moderator variable perspective. Psychology \& Marketing, 11(6), 549-568. http://dx.doi.org/10.1002/ mar.4220110604

23. Mitchell, V., \& Walsh, G. (2004). Gender differences in German consumer decisionmaking styles. Journal of Consumer Behavior, 3(4), 331-346. http://dx.doi.org/10.1002/cb.146

24. Mitchell, V.W., \& Bates, L. (1998). UK Consumer decision making styles. Journal of Marketing Management, 14(1-3), 199-225. http://dx.doi.org/10.1362/02672579878495934

25. Morganosky, M.R., \& Lazarde, M.M. (1987), Foreign-made apparel influence on consumers' perceptions of brand and store quality. International Journal of Advertising, 6, 338-346.

26. Olsen, J.E., Granzin, K.L., \& Biswas, A. (1993). Influencing consumers' selection of domestic versus imported products: implications for marketing based on a model of helping behavior. Journal of the Academy of Marketing Science, 21(4), 307-321. http://dx.doi. org $/ 10.1177 / 0950017091005002007$

27. Orbaiz, L.V., \& Papadopoulos, N. (2003). Toward a model of consumer receptivity of foreign and domestic products. Journal of International Consumer Marketing, 15(3), 101-126. http://dx.doi.org/10.1300/J046v15n03_06

28. Piron, F. (2000). Consumers' perceptions of the country-of-origin effect on purchasing intentions of (in) conspicuous products. Journal of Consumer Marketing, 17(4), 308-321. http:// dx.doi.org/10.1108/07363760610641145

29. Shankarmahesh, M. N. (2006). Consumer ethnocentrism: an integrative review of its antecedents and consequences. International Marketing Review, 23(2), 146-172. http://dx.doi. org/10.1108/02651330610660065

30. Sharma, S., Shimp, T. A., \& Shin, J. (1995). Consumer ethnocentrism: a test of antecedents and moderators. Journal of the Academy of Marketing Science, 23(1), 26-37. http://dx.doi. org/10.1007/BF02894609

31. Shimp, T., \& Sharma, S. (1987). Consumer ethnocentrism: construction and validation of the cetscale. Journal of Marketing Research, 14(3), 280-289. http://dx.doi.org/10.2307/3151638

32. Siemieniako, D., Kubacki, K., Glin’ska, E., \& Krot, K. (2011). National and regional ethnocentrism: a case study of beer consumers in poland. British Food Journal, 113(3), 404418. http://dx.doi.org/10.1108/00070701111116464

33. Sproles, G. B. (1985). From perfectionism to dadaism: measuring consumers' decision-making styles. American council on consumer interest on Columbus, OH, 79-85.

34. Sproles, G. B., \& Kendall, E. (1986). A methodology for profiling consumers decisionmaking styles. The journal of Consumer Affairs, 20(2), 267-279. http://dx.doi.org/10.1111/ j.1745-6606.1993.tb00737.x

35. Suh, T., \& Kwon, I.W.G. (2002). Globalization and reluctant buyers. International Marketing Review, 19(6), 663-672. http://dx.doi.org/10.1108/20400701111110786

36. Sumner, W. G. (1906). Folkways: The sociological importance of usages, manners, customs, mores, and morals. NY: Harper \& Row. 
37. Toyne, B., \& Walters, P.G.P. (1989), Global Marketing Management: A Strategic Perspective. Boston, MA: Allyn \& Bacon.

38. Vida, I., Dmitrovic', T., \& Obadia, C. (2008). The role of ethnic affiliation in consumer ethnocentrism. European Journal of Marketing, 42(3/4), 327-343. http://dx.doi.org/10.1108/03 090560810852968

39. Walsh, G., Hennig-Thurau, T., Wayne-Mitchell, V., \& Wiedmann, K. P. (2001). Consumers' decision-making style as a basis for market segmentation. Journal of Targeting, Measurement \& Analysis for Marketing, 10(2), 117-131. http://dx.doi.org/10.1057/palgrave.jt.5740039

40. Wang, C.L., Chen, Z.X., Chan, A.K.K. \& Zheng, Z.C. (2000). The influence of hedonic values on consumer behaviors: an empirical investigation in China. Journal of Global Marketing, 14(1/2), 169-186. http://dx.doi.org/10.1300/J042v14n01_09

41. Wang, L. C., \& Chen, X. Z. (2004). Consumer ethnocentrism and willingness to buy domestic products in a developing country setting: testing moderating effects. Journal of Consumer Marketing, 21(6), 391-400. http://dx.doi.org/10.1108/07363760410558663

42. Wanninayake, W.M.C.B., \& Chovancova, M. (2012). Consumer Ethnocentrism and Attitudes towards Foreign Beer Brands: With Evidence from Zlin Region in the Czech Republic. Journal of Competitiveness, 4(2), 3-19. http://dx.doi.org/10.7441/joc.2012.02.01

43. Yasin, B. (2009). The Role of Gender on Turkish Consumers' Decision-Making Styles. Advances in Consumer Research - Asia-Pacific Conference Proceedings, 8, 301-308.

44. Zarkada-Fraser, A., \& Fraser, C. (2002). Store patronage prediction for foreign-owned supermarkets. International Journal of Retail \& Distribution Management, 30(6), 282-299. http:// dx.doi.org/10.1108/09590550210429504

\section{Contact information}

W.M.C.Bandara Wanninayake, PhD.

Department of Marketing Management

Faculty of Commerce and Management Studies

University of Kelaniya, Colombo, Sri Lanka

Email:bwanninayake@gmail.com 